\title{
Menelisik Eksistensi Restoran Lake View Kintamani Di Tengah Pandemi Covid-19
}

\author{
Kadek Ayu Anjani Rosmiati ${ }^{\star 1}$, I.A Oka Martini ${ }^{2}$ A.A Ngr Oka Suryadinatha Gorda. ${ }^{2}$, \\ A.A Ngr Oka Suryadinatha ${ }^{3}$, Ketut Gede Sri Diwya ${ }^{4}$
}

1,2,3,4 Program Studi Manajemen

Universitas Pendidikan Nasional

Denpasar, Indonesia

\begin{abstract}
e-mail: anjanirosmiati6@gmail.com¹, dayuokamartini@undiknas.ac.id², okagorda@undiknas.ac.id ${ }^{3}$, amararaja88@gmail.com ${ }^{4}$
\end{abstract}

\section{Riwayat Artikel Tanggal diajukan: 2 Oktober 2021 \\ Tanggal diterima 9 November 2021 \\ Tanggal dipublikasikan: 15 Desember 2021}

Pengutipan:

Rosmiati, K. A. A. et al (2021).

Menelisik

Eksistensi

Restoran Lake

View Kintamani di

Tengah Pandemi

Covid-19. Jurnal

Pendidikan

Ekonomi

Undiksha, 13 (2),

378-385

http://dx.doi.org/1 $\underline{0.23887 / j i p e . v 13 i}$ 2.39930

\begin{abstract}
Abstrak
\end{abstract}
Bali dikenal dengan keindahan alamnya yang menjadi daya tarik pariwisata. Salah satunya adalah Kintamani dengan view Gunung Batur, Danau Batur dan objek wisata lainnya membuat Kintamani banyak dikunjungi wisatawan. Banyaknya kunjungan Wisatawan ke Kintamani memberikan peluang bagi masyarakat sekitar untuk membuka suatu usaha. Peluang tersebut pun digunakan oleh PT Armainusa Wiwayuta untuk membuka sebuah restoran dengan nama Restoran Lake View Kintamani. Restoran yang berdiri sejak tahun 1972 ini masih beroperasi dengan baik ditengah banyaknya kompetitor dan pandemi Covid-19. Eksistensi yang masih terjaga dipengaruhi oleh beberapa faktor yaitu keindahan alam, inovasi menu,keramahan pelayanan, dan sudah tersertifikasi CHSE Standard oleh Kementerian Pariwisata dan Ekonomi Kreatif. Dengan faktor tersebut tentu tidak lepas dari pengelolaan internal sumber daya manusianya, sehingga penelitian ini dilakukan untuk mengetahui bagaimana kinerja karyawan dalam mempertahankan eksistensi Restoran Lake View Kintamani ditengah pandemi Covid-19. Dengan menggunakan metode deskriptif kualitatif dan teknik pengumpulan data melalui observasi,wawancara dan dokumentasi. Data Primer diperoleh dari hasil observasi dan wawancara, sedangkan data sekunder dari studi pustaka terdahulu seperti jurnal dan buku. Berdasarkan analisis data maka kesimpulan dari penelitian ini adalah dalam memeprtahankan eksistensi restoran Lake View Kintamani ditengah Pandemi Covid-19 ini adalah dengan kualitas sumber daya manusia yang baik sehingga menghasilkan kinerja yang unggul, dalam rekrutmen karyawan lebih mempertimbangkan skill yang dimiliki, pelatihan dan evaluasi adalah cara untuk mengembangkan kinerja karyawan serta mengetahui kendala yang dihadapi. Dalam mempertahankan kinerja yang baik, Restoran Lake View secara rutin memberikan motivasi berupa reward terhadap karyawan yang berprestasi.

Kata Kunci: Eksistensi; Kinerja Karyawan; Pandemi Covid-19; Pariwisata

\begin{abstract}
Bali is known for its natural beauty which is a tourist attraction. One of them is Kintamani with views of Mount Batur, Lake Batur and other tourist attractions that make Kintamani visited by many tourists. The number of tourist visits to Kintamani provides opportunities for the surrounding community to open a business. PT Arminusa Wiwayuta also used this opportunity to open a restaurant with the name Lake View Kintamani Restaurant. The restaurant, which was founded in 1972, is still operating well amidst the many competitors and the Covid-19 pandemi. The existence that is still maintained is influenced by several factors, namely natural beauty, menu innovation, friendly service, and has been certified CHSE Standard by the Ministry of Tourism and Creative Economy. With these factors, of course, it
\end{abstract}


cannot be separated from the internal management of human resources, so with this phenomenon the purpose of this study is to find out how the performance of employees in maintaining the existence of the Lake View Kintamani Restaurant in the midst of the Covid-19 pandemi. By using descriptive qualitative methods and data collection techniques through observation, interviews and documentation. Primary data obtained from observations and interviews, while secondary data from previous literature studies such as journals and books. Based on data analysis, the conclusion of this study is that in maintaining the existence of the Lake View Kintamani restaurant in the midst of the Covid-19 pandemi, the quality of human resources is good so as to produce superior performance, in recruiting employees more consider the skills possessed, training and evaluation are ways to develop employee performance and find out the obstacles faced. In maintaining good performance, Lake View Restaurant routinely provides motivation in the form of rewards for employees who excel.

Keywords : Existence; Employee Performance; Covid-19 Pandemic Tourism

\section{PENDAHULUAN}

Pariwisata di Bali sudah sangat dikenal oleh mancanegara, keindahan yang terlahir secara alami ini membuat pesona Bali semakin memikat wisatawan untuk berkunjung. Kintamani merupakan salah satu pilihan desitinasi wisata saat berkunjung ke Bali. Keindahan Gunung Batur dan Danau Batur yang terletak di Kintamani sangat menarik minat wisatawan lokal maupun mancanegara. Banyaknya kunjungan wisatawan ke Kintamani khususnya Desa Batur tentu memberikan peluang bagi masyarakat sekitar untuk mengembangkan potensi usaha yang dapat menunjang pariwisata Kintamani. Potensi usaha yang dapat dikembangkan salah satunya adalah restoran atau kedai kopi dengan view Gunung Batur ataupun Danau Batur yang tentunya akan menambah daya tarik pariwisata tersebut.

Restoran atau rumah makan merupakan sebuah tempat yang menawarkan beragam makanan dan minuman yang dapat dinikmati oleh pengunjungnya dimana bangunan yang diorganisasikan secara komersial yang memeprkerjakan karyawan (Fathoni \& Hius, n.d.). Restoran merupakan salah satu usaha yang berkembang pesat, hal ini dikarenakan tempat makan sangat penting bagi semua orang serta dengan pemandangan yang menarik tentu akan menambah minat pengunjung.
PT. Armainusa Wiwayuta merupakan salah satu perusahaan di daerah Kintamani, Bali yang bergerak pada bidang industri pariwisata khususnya restoran yang di kenal dengan nama Restoran Lake View Kintamani, berdiri sejak Tahun 1972 ini berlokasi di dekat Objek wisata Gunung batur, tepatnya Jalan utama Penelokan, Batur, Kintamani, Bangli. Restoran dengan view Gunung Batur ini juga menyediakan bar dan café, sehingga restoranLake View Kintamani adalah salah satu tempat yang paling banyak dikunjungi sebagai tempat makan, bersantai dengan menikmati pemandangan yang menarik. Namun, dengan adanya pandemi Covid-19 pariwisata di Bali dihentikan dalam beberapa waktu yang juga berdampak pada Restoran Lake View Kintamani karena harus ditutup sementara. Lebih dari 1.000 Restoran tutup permanen karena adanya pandemi Covid-19 (Kontan.co.id News, n.d.). Namun, pada awal Juli 2020 pariwisata Bali kembali dibuka untuk Mayarakat lokal (Aditya, n.d.) sehingga Restoran Lake View Kintamani kembali dibuka dengan menerapkan protokol kesehatan sesuai dengan kebijakan Pemerintah. Dengan adanya penutupan sementara yang diakibatkan oleh pandemi Covid-19 tentu jumlah pengunjung Tahun 2020 pada Restoran Lake View Kintamani mengalami penurunan seperti terlihat pada tabel 1. 
p-ISSN : 2599-1418

e-ISSN : 2599-1426

Tabel 1

Jumlah Pengunjung Restoran Lake View Kintamani

\begin{tabular}{cc}
\hline Tahun & Jumlah Pengunjung \\
\hline 2017 & 12.912 \\
2018 & 11.826 \\
2019 & 10.777 \\
2020 & 3.618 \\
\hline
\end{tabular}

Sumber : Restoran Lake View Kintamani

Pandemi Covid-19 merupakan tantangan baru bagi Restoran Lake View Kintamani dan seiring dengan semakin banyaknya bisnis sejenis, berupa restoran maupun coffeshop mengakibatkan beberapa risiko yang kemungkinan terjadi akibat persaingan yang ketat. Apabila tidak melakukan inovasi maka konsumen akan beralih ke tempat lain yang lebih menarik. Tentunya akan menjadi sebuah ancaman bagi restoran Lake View Kintamani.

Akan tetapi, ancaman tersebut dapat diatasi oleh Restoran Lake View Kintamani dilihat dari Restoran Lake View Kintamani dapat mempertahankan eksistensinya dan tetap ramai dikunjungi oleh wisatawan, hal ini dipengaruhi oleh beberapa faktor yaitu: Keindahan view gunung batur dan danau batur yang dapat dilihat dengan jelas dari restoran, Inovasi menu yang beragam, Pelayanan karyawan yang ramah, Sertifikasi CHSE oleh Kementerian Pariwisata dan Ekonomi Kreatif. Sehingga dengan faktor tersebut Restoran Lake View Kintamani masih banyak dikunjungi dan eksis sampai saat ini, meskipun begitu banyak bisnis sejenis yang kian marak bermunculan. Berbeda dengan beberapa bisnis sejenis lainnya, dimana para karyawan yang bekerja hanya fokus pada tugas yang dikerjakan, akan tetapi di pada Restoran Lake View Kintamani seperti memiliki suatu "perbedaan" karena para karyawan tersebut begitu mementingkan aspek pelayanan dan keramahan yang ditunjukkan, inovasi menu yang ditawarkan, bahkan terkadang ikut pula berbaur untuk berkomunikasi dengan para pengunjung yang datang sembari menikmati makanan yang disajikan dan memberikan informasi tentang alam sekitarnya. Selain itu, antar karyawan pun terlihat begitu akrab
Jurnal Pendidikan Ekonomi Undiksha

Vol. 13 No. 2 (2021)

satu sama lain disaat menjalankan tugasnya. Hal seperti ini yang terkadang justru tidak diperhatikan oleh bisnis sejenis lainnya sehingga tidak dapat bertahan lama karena tidak mendapat kepercayaan dari para pengunjung. Dengan kata lain, salah satu kunci keberhasilan berjalannya unit bisnis dengan baik yaitu terletak pada aspek pengelolaan internal atau sumber daya manusia yang bekerja sehingga akan menghasilkan kinerja yang unggul.

Adapun dari fenomena yang dapat diangkat dalam ruang lingkup manajemen sumber daya manusia ini, membuat peneliti ingin mengetahui lebih dalam dan meneliti Restoran Lake View Kintamani. Peneliti ingin mengetahui bagaimana Kinerja Karyawan dalam mempertahankan eksistensi Restoran Lake View Kintamani di tengah Pandemi Covid-19. Berdasarkan fenomena tersebut, peneliti ingin mengetahui lebih dalam dengan judul "Menelisik Eksistensi Restoran Lake View Kintamani di tengah Pandemi Covid-19".

Secara Teoritis Hasil penelitian diharapkan dapat memberikan inspirasi pada peneliti lain dalam ilmu manajemen khususnya pada konsentrasi manajemen sumber daya manusia yang berkaitan dengan kinerja karyawan dalam mempertahankan eksistensi ditengah pandemi Covid-19 pada Restoran Lake View Kintamani. Serta Kegunaan Praktis diharapkan dapat memberikan masukan bagi Restoran Lake View Kintamani berkaitan dengan kinerja karyawan dan juga penelitian diharapkan dapat memberikan masukan tentang hal-hal yang belum diamati oleh Restoran Lake View Kintamani dalam kinerja karyawan.

\section{METODE}

Kinerja merupakan bentuk upaya dalam memperoleh hasil yang optimal dalam organisasi, kelompok dan individu melalui pemahaman dan menjelaskan kinerja dalam rangka tujuan, standar dan persyaratan atribut atau kompetensi yang disepakati bersama. Menurut Koopmans, et al. (Irdiana \& Sulistyan, 2017) kinerja merupakan tindakan dan perilaku yang sesuai dengan 
p-ISSN : 2599-1418

e-ISSN : 2599-1426

tujuan organisasi. Menurut Robbins (A. D. Dewi, 2019) kinerja merupakan mengukur hasil kerja berdasarkan pencapaian yang diraih sesuai dengan tujuan organisasi secara optimal. Dessler, (Pradita, 2017)mendefinisikan kinerja adalah prestasi kerja dengan membandingkan hasil kerja dan standar yang diterapkan.

Menurut Furtwengler (Sekartini, 2016) indikator kinerja adalah kreatifitas, kualitas pekerjaan, kuantitas pekerjaan, keterampilan interpersonal dan cepat dalam menyelesaikan pekerjaan. Robbins (A. D. Dewi, 2019) mengemukakakan bahwa terdapat 5 (lima) indikator kinerja yang digunakan sebagai alat ukur prestasi kerja karyawan,yaitu yang pertama Kualitas Kerja dapat diukur melalui persepsi dari karyawan terhadap hasil kerja yang dihasilkan serta kemampuan dan keterampilan karyawan, Kualitas dapat dianyatakan dalam bentuk jumlah siklus,jumlah unit, dan jumlah aktivitas yang dihasilkan, Ketepatan Waktu adalah kemampuan untuk bekerja dengan memaksimalkan waktu dapat dilihat dari output yang dihasilkan, Efektivitas dapat dinyatakan dengan penggunaan sumber daya yang dapat menaikkan setiap unit hasil dari penggunaan sumber daya tersebut, Kemandirian dapat diukur dari seorang karyawan dapat menuntaskan pekerjaannya, dan Komitmen kerja merupakan tingkat komitmen yang dimiliki karyawan terhadap instansi atau perusahaan dan tanggung jawab terhadap pekerjaan.

Le Tran dan Chiou-su (N. Dewi \& Utama, 2016) mengemukakan beberapa faktor yang mempengaruhi kinerja karyawan, diantaranya: Kepemimpinan, yaitu melibatkan sebuah proses seorang individu yang dapat mempengaruhi sekelompok orang, coaching merupakan proses memaksimalkan potensi yang menjadi faktor penting untuk meningkatkan kinerja karyawan seperti pelatihan terhadap karyawan, manajemen partisipasi yaitu melibatkan karyawan dalam mengambil keputusan sehingga setiap karyawan dapat berkesempatan untuk memberikan ide atau pemikirannya terhadap perusahaan,
Jurnal Pendidikan Ekonomi Undiksha

Vol. 13 No. 2 (2021)

motivasi sangat penting dan berpengaruh dalam meningkatkan kinerja karyawan sehingga manajemen perlu untuk selalu memberikan motivasi terhadap karyawannya.

Kinerja karyawan tidak sekedar patokan gaji bagi perusahaan, namun juga sebagai cara perusahaan dalam memotivasi karyawan dan mengembangkan satu rencana dalam antisipasi penurunan kinerja. Hasil kerja yang dicapai karyawan harus terukur dan dapat dinyatakan baik kuantitas maupun kualitasnya dalam melaksanakan dan bertanggungjawab atas pekerjaannya. Menurut Kaswan (Suryani \& Ningsih, 2019)dalam mendorong kinerja, dengan kinerja baik yang berulang maka pemimpin harus memberikan reward bagi karyawan untuk mngehargai hasilnya dan memberikan di waktu yang tepat secara adil. Berdasarkan definisi yang telah dipaparkan diatas, peneliti menarik kesimpulan bahwa kinerja karyawan adalah hasil kerja karyawan yang dijalankan sesuai dengan standar serta tujuan yang telah ditetapkan dengan batasan-batasan tertentu.

Coronavirus yang mewabah diberbagai belahan dunia merupakan suatu virus yang dapat menyebabkan gejala baik gejala ringan maupun berat. Coronavirus Disease 19 (Covid-19) adalah penyakit virus baru yang belum pernah teridentifikasi sebelumnya di tubuh manusia. Beberapa gejala disebabkan oleh Covid-19 seperti demam, sesak pada pernafasan dan batuk. Pada tanggal 30 Januari ditetapkan sebagai kedaruratan kesehatan di dunia. Indonesia mengkonfirmasi laporan Covid-19 pertama kalinya pada tanggal 2 Maret 2020. Virus corona ini sangat berdampak bagi seluruh warga Indonesia Yurianto,Ahmad,Bambang Wibowo (Suryani \& Ningsih, 2019). Berbagai aspek terdampak akibat adanya Covid-19 ini yaitu bidang ekonomi,sosial,pariwisata dan pendidikan. Surat Edaran Pemerintah tanggal 18 Maret 2020 mengatur tentang segala kegiatan yang berada didalam maupun diluar ruangan, semua sektor diberhentikan untuk sementara waktu demi antisipasi penyebaran Covid-19. (Kompas, 28 Maret 2020). 
p-ISSN : 2599-1418

e-ISSN : 2599-1426

Penyebaran Covid-19 ke seluruh duinia dikatakan sebagai Pandemi menurut WHO pada tanggal 9 Maret 2020. Pandemi merupakan suatu gambaran dari penyakit yang menyebar dengan cepat dan secara luas. Covid-19 dapat menyebabkan masalah kesehatan yang serius, sehingga sangat penting dalam membantu mengurasi resiko penularan Covid-19. Pandemi Covid-19 ini merupakan krisis yang datang tidak terduga hal ini disebabkan karena suatu Negara berada ada siatuasi yang penuh dengan ketidakpastian dalam berbagai sektor. Berbagai upaya Pemerintah terus dilakukan dalam menghentikan penyebaran rantai Covid-19 di berbagai belahan dunia.

Penlitian ini berlokasi di Restoran Lake View Kintamani, Desa Penelokan, Kabupaten Bangli, Bali. Restoran Lake View Kintamani yang berdiri sejak Tahun 1972 adalah Restoran pertama di Kintamani yang memiliki view gunung Batur dengan keindahannya. Ditengah ketatnya persaingan dengan kompetitor baru di sekitar Restoran Lake View Kintamani, membuat restoran ini terus berinovasi untuk meningkatkan kualitasnya. Menu yang disajikan lebih berinovasi, tentu tidak lepas dari peran karyawan yang bekerja di Restoran Lake View Kintamani. Peran kinerja karyawan yang baik dan berkualitas akan dapat mempertahankan eksistensi Restoran Lake View Kintamani.

Teknik Pengumpulan Data yang pertama adalah Observasi Dalam melakukan penelitian teknik pengumpulan pertama yang dilakukan oleh peneliti ialah observasi pada lokasi penelitian. Observasi yang peneliti lakukan adalah mengetahui suasana pada lokasi penelitian, karyawan yang sedang bekerja, menu yang terdapat,view Restoran Lake View Kintamani,keramaian customer, serta cara atau proses karyawan melayani pengunjungnya. Berikutnya ialah Wawancara Teknik pengumpulan data yang berikutnya digunakan adalah wawancara dengan informan. Wawancara dalam penelitian dilakukan dengan teknik posrposive sampling atau didasarkan dari ciri ciri yang mendekati tujuan penelitian
Jurnal Pendidikan Ekonomi Undiksha

Vol. 13 No. 2 (2021)

dalam hal ini yaitu Manager, Human Resources Development (HRD), karyawan dan pengunjung Restoran Lake View Kinatamani. Proses wawancara yang dilakukan dengan in-depth interview atau wawancara mendalam. Setelah wawancara teknik berikutnya adalah Dokumentasi,Teknik pengumpulan data yang juga digunakan oleh peneliti ialah melalui media dokumentasi . Seperti Instagram account Restoran Lake View Kintamani yang ditunjukkan pada gambar berikut ini.

Menurut Miles et al. (Shidiq \& Choiri, 2019) pada penelitian kualitatif analisis data yang dilakukan hingga jenuh dengan menggunakan tiga cara yaitu, data reduction, data display dan conclusion drawing/ verification.

Reduksi Data adalah suatu proses untuk penyempurnaan data, dengan melakukan pengurangan terhadap data yang tidak relevan dan kurang perlu. Data yang diperoleh jumlahnya banyak sehingga diperlukan reduksi data yang dapat digunakan untuk merangkum, memilah informasi pokok, dan memfokuskan pada data yang penting. Dengan melakukan reduksi data maka dapat memberikan gambaran yang lebih jelas dan mempermudah peneliti untuk melakukan pengumpulan data selanjutnya.

Penyajian Data (Data Display )

Setelah meredukkusi data, selanjutnya ialah menyajikan data. Pada umumnya data yang disajikan pada penelitian kualitatif yaitu dalam bentuk teks yang bersifat naratif.

Verifikasi Data (Conclusions drowing/verifiying)

Langkah yang terakhir dalam melakukan analisis data ialah verifikasi data. Verifikasi data dilakukan apabila kesimpulan Pemeriksaan keabsahan data digunakan untuk hal lain diluar data sebagai pengecekan atau digunkaan dalam membandingkan data tersebut. Keabsahan data yang dilakukan adalah untuk memastikan bahwa penelitian bersifat ilmiah dan untuk melakukan uji data yang diperoleh. Agar data yang ada pada penelitian kualitatif ini dapat 
p-ISSN : 2599-1418

e-ISSN : 2599-1426

dipertanggungjawabkan maka perlu melakukan uji keabsahan data. Uji keabsahan data yang peneliti dapat lakukan adalah Triangulasi Sumber yaitu dalam melakukan uji kredibilitas data maka dilakukan dengan cara memastikan data yang diperoleh dari beberapa sumber. Setelah memperoleh data, peneliti menganalisis data untuk menghasilkan sebuah kesimpulan dan dilanjuutkan kesepakatan dengan sumber data dan triangulasi teknik yang merupakan uji kreadibilitas data dengan cara cek data kepada sumber yang sama namun dengan teknik yang berbeda menurut Sugiyono, (Sasmito \& Nawangsari, 2019). Dalam melakukan penlitian maka teknik yang digunakan oleh peneliti antara lain observasi, wawancara dan dokumentasi.

\section{HASIL DAN PEMBAHASAN}

Berdasarkan dari temuan penelitian yang dilakukan dengan wawancara dari 7 (tujuh) informan yaitu Manager Restoran, HRD, 3 karyawan dan 2 pengunjung, hasil penelitian ini memperkuat teori dari Robbins (A. D. Dewi, 2019)yaitu :

Kinerja Karyawan restoran Lake View Kintamani dapat dilihat dari hasil kerja yaitu berupa kuantitas atau output berupa inovasi baru yang dihasilkan oleh karyawan dalam mempertahankan eksistensi Restoran Lake View Kintamani ditengah Pandemi Covid-19. Inovasi yang ada padarestoran Lake View Kintamani seperti perubahan menu dari menu khas nusantara sampai dengan wester food, adanya penambahan ornament seperti balon udara, free swing, camping dan galmping merupakan hasil kinerja karyawan yang baik sesuai dengan tujuan restoran untuk mengembangkan potensi dan sumber daya yang dimiliki dalam menarik minat pengunjung Restoran Lake View Kintamani. Indikator Kinerja pada Restoran Lake View Kintamani yaitu :

Kualitas Kerja Karyawan Restoran Lake View Kintamani dapat dilihat dari setiap karyawan yang memiliki kehalian/skill pada bidang masing-masing. Skill merupakan syarat khusus saat melakukan rekrutmen
Jurnal Pendidikan Ekonomi Undiksha

Vol. 13 No. 2 (2021)

karyawan pada Restoran Lake View Kintamani.

Restoran Lake View Kintamani diukur dari kemampuan karyawan dalam memaksimalkan waktu seperti waitress/waiter yang dapat melayani banyak pengunjung dan efektif dalam menyelesaikan tugasnya dari melayani, menyiapkan service,table set-up dan clear up, mengambil pesanan pengunjung hingga menyajikannya kepada pengunjung. Ditengah Pandemi Covid-19 ini tentu efektivitas karyawan sangat dibutuhkan terlihat dari jumlah shift kerja karyawan yang dibagi menjadi dua shift tentu karyawan yang bekerja jumlahnya tidak sama saat kondisi normal dan pada Restoran Lake View Kintamani tetap bisa melayani pengunjung yang ramai dengan penggunaan sumber daya manusia yang lebih sedikit dari biasanya.

Kemandirian karyawan pada Restoran Lake View Kintamani terkhusus saat pandemi Covid-19 ini dapat dilihat dari bagaimana setiap karyawan menyelesaikan pekerjaannya dan mengatasi masalah yang ada dan karyawan diharapkan dapat memahami semua bidang kerja pada restoran Lake View Kintamani ini agar apabila ada yang menyangkut pada salah satu bidang dapat ditangani oleh semua staff.

Pelayanan yang ramah terhadap pengunjung harus dapat dikuasai oleh semua karyawan karena itu merupakan fokus dari restoran ini dalam mempertahankan eksistensinya.

Komitmen kerja karyawan sangat dibutuhkan untuk mempertahankan esksitensi Restoran Lake View Kintamani ditengah Pandemi Covid-19 ini, bertahannya restoran pertama di Kintamani ini sampat dengan sekarang tentu tidak terlepas dari tanggung jawab karyawan terhadap pekerjaannya, bahkan karyawan di restoran Lake View Kintamani ini ada yang sudah bekerja lebih dari dua puluh Tahun.

Hasil penelitian ini juga memperkuat teori dari Le Tran dan Chiou-su dalam (N. Dewi \& Utama, 2016) yaitu : 
p-ISSN : 2599-1418

e-ISSN : 2599-1426

Kepemimpinan pada Restoran Lake View Kintamani terlihat sangat jelas ketika pemimpin dalam hal ini adalah general manager yang fokus pada keramahan pelayanan dan diterapkan serta diikuti oleh seluruh karyawannya yang menjadikan restoran ini memiliki 'perbedaan' dengan kompetitor sejenis selain itu dengan keramahan ini juga dapat mempertahankan eksistensi restoran Lake View Kintamani, terkadang pimpinan juga ikut berbaur dengan pengunjung restoran.

Coaching adalah Pelatihan karyawan dalam hal ini diberikan secara rutin sebagai salah satu bentuk upaya dalam mempertahankan eksistensi Restoran Lake View Kintamani, apabila akan diluncurkan sebuah inovasi baru, maka dipastikan seluruh karyawanya sudah mengetahui dan memahami akan inovasi tersebut sehingga dapat sejalan dengan target yang telah ditentukan restoran Lake View Kintamani.

Participation Restoran Lake View Kintamani secara rutin mengadakan evaluasi untuk karyawannya, dalam evaluasi tersebut manajer mempersihlahkan karyawannya untuk menyampaikan kendala atau hambatan yang dihadapi dan juga manajer memberi ruang untuk karyawan yang memiliki sebuah ide untuk memberikan inovasi baru bagi Restoran Lake View Kintamani, baik berupa penambahan menu maupun ide lain yang relevan.Partisipasi dari karyawan juga sangat penting karena ide unik muncul tidak dari satu pihak sehingga Restoran Lake View juga selalu melibatkan karyawannya. Motivation Dalam meningkatkan kinerja karyawan restoran Lake View Kintamani terlebih di situasi pandemi seperti sekarang ini, tentunya karyawan memerlukan sebuah motivasi.

Motivasi yang restoran Lake View Kintamani berikan kepada karyawan untuk dapat mempertahankan kinerja yang baik secara berulang adalah penghargaan atau reward berupa uang atau barang sebagai bentuk penghargaan dan rasa terimakasih Restoran Lake View kepada karyawannya yang sudah maksimal dalam melakukan pekerjaan. Tentu dengan adanya reward ini membuat karyawan lebih semangat untuk
Jurnal Pendidikan Ekonomi Undiksha

Vol. 13 No. 2 (2021)

menghasilkan kinerja yang baik dan ini merupakan faktor penting dalam mempertahankan eksistensi Restoran Lake View Kintamani ditengah Pandemi Covid-19.

\section{SIMPULAN DAN SARAN}

Berdasarkan Hasil pembahasan mengenai kinerja karyawan dalam mempertahankan eksistensi Restoran Lake View Kintamani, maka dapat ditarik kesimpulan sebagai berikut.

Dalam mempertahankan eksistensi Restoran Lake View Kintamani ditengah Pandemi Covid-19 didukung oleh aspek internal pengelolaan sumber daya manusia yang baik sehingga menghasilkan kinerja karyawan yang unggul ditunjukkan dari indikator kinerja Restoran Lake View Kintamani yaitu kualitas ,kuantitas , ketepatan waktu,efektivitas, kemandirian dan komitmen kerja karyawan.

Mengoperasionalkan inovasi yang akan diluncurkan untuk mempertahankan eksistensi ditengah pandemi Covid-19, selain itu Restoran Lake View Kintamani sudah tersertifikasi CHSE Standard oleh Kementerian Pariwisata dan Ekonomi Kreatif tentu hal tersebut tidak lepas dari faktor yang mempengaruhi kinerja karyawan pada Restoran Lake View Kintamani yaitu Kepemimpinan, Pelatihan, Partisipasi dan Motivasi.

Adapun saran yang dapat dieberikan dalam penelitian ini adalah sebagai berikut :

Restoran Lake View Kintamani diharapkan dapat mempertahankan eksistensinya dengan memperhatikan protokol kesehatan karena ditengah pandemi Covid-19 selain inovasi, keselamatan pengunjung juga menjadi bagian penting, salah satunya dengan membuat $Q R$ Code Menus yang dapat discan oleh pengunjung sehingga megurangi contac langsung antara pengunjung dengan karyawan, serta pekerjaan menjadi lebih efisien dan lebih praktis.

Manajemen Restoran Lake View Kintamani sebaiknya menyusun ketentuan yang penting untuk karyawan seperti Standar Operasional Prosedur (SOP), Tata 
Tertib, Sanski, Struktural Bisnis, dan yang berkaitan dengan administratif restoran. Meskipun dapat dijelaskan secara lisan dan langsung dilapangan namun akan lebih baik bila dapat dibuat berbentuk sebuah buku pedoman mengenai operasional restoran Lake View Kintamani. Dengan adanya administratif yang jelas maka karyawan dapat lebih efektif dalam bekerja dan mengetahui apa saja yang menjadi hak dan tanggung jawabnya.

Pimpinan dan manajemen Restoran Lake View Kintamani sebaiknya menyediakan survey penilaian digital dan saran dari pengunjung seperti google form yang berisi kuisioner tentang kinerja karyawan sehingga restoran ini memiliki data penilaian kinerja yang dapat mempermudah pimpinan untuk mengetahui dan mengukur bagaimana kinerja karyawan di restoran Lake View Kintamani.

\section{DAFTAR PUSTAKA}

Aditya, N. R. (n.d.). Pariwisata Bali buka pada Juli 2020, Terbatas untuk Wisatawan Lokal. https://travel.kompas.com/read/2020/0 6/21/210200927/pariwisata-bali-bukapada-juli-2020-terbatas-untukwisatawan-lokal?page $=$ all

Dewi, A. D. (2019). Pengaruh Pelatihan dan Motivasi Kerja Terhadap Kinerja Karyawan Perusahaan Daerah Pasar Surya Surabaya.

Dewi, N., \& Utama, I. (2016). Pengaruh Pengembangan Karir Terhadap Kinerja Karyawan Melalui Mediasi Motivasi Kerja Pada Karya Mas Art Gallery. EJurnal Manajemen Universitas Udayana, 5(9), 254949.

Fathoni, M., \& Hius, J. J. (n.d.). Aplikasi Pemesanan Makanan Pada Restoran Perancangan Dan Implement asi Aplikasi Pemesanan Makanan Dan Minuman Berbasis Client Server D... Ariez Rachman Seminar Nasional dan ExpoTeknik Elekt ro 2013 Rancang Bangun Aplikasi Menu Rest oran dan Warung ....

Irdiana, S., \& Sulistyan, R. B. (2017). Dampak Budaya Organisasi Terhadap
Motivasi Dan Organizational Citizenship Behavior.

Kontan.co.id News. (n.d.). Ada lebih 1.000 Restoran Tutup Permanen akibat Pandemi.

https://industri.kontan.co.id/news/adalebih-1000-restoran-tutup-permanenakibat-pandemi

Pradita, M. Y. (2017). Pengaruh Kompensasi, Gaya Kepemimpinan Dan Karakteristik Tenaga Pemasar Terhadap Motivasi Dan Kinerja Tenaga Pemasar Pada Pt. Bank Rakyat Indonesia (Persero) Tbk. Cabang Jombang. Jurnal Bisnis Dan Manajemen, 4(2), 153-164. https://doi.org/10.26905/JBM.V4I2.169 7

Sasmito, C., \& Nawangsari, E. R. (2019). Implementasi Program Keluarga Harapan Dalam Upaya Mengentaskan Kemiskinan Di Kota Batu. JPSI (Journal of Public Sector Innovations), 3(2), 6874.

https://doi.org/10.26740/JPSI.V3N2.P6 8-74

Sekartini, N. L. (2016). Pengaruh Kemampuan Kerja, Disiplin Kerja, Motivasi Kerja Terhadap Kepuasan Kerja Dan Kinerja Karyawan Administrasi Universitas Warmadewa. Jurnal Ekonomi \& Bisnis JAGADITHA, 3(2), 64-75. https://doi.org/10.22225/JJ.3.2.130.6475

Shidiq, U., \& Choiri, M. (2019). Metode Penelitian Kualitatif di Bidang Pendidikan. In Journal of Chemical Information and Modeling (Vol. 53, Issue 9).

Suryani, S., \& Ningsih, S. (2019). Pengaruh Kompensasi Finansial Dan Kompensasi Non Finansial Terhadap Kinerja Karyawan Bagian Akuntansi Pada Perbankan Di Tembilahan. Jurnal Akuntansi Dan Keuangan, 8(2), 73-84. 